Dhaka Univ. J. Biol. Sci. 27(1): 69-74, 2018 (January)

\title{
ANATOMICAL STUDY OF MOMORDICA CHARANTIA L. FROM BANGLADESH
}

\author{
Kishwar Jahan Shethi* ${ }^{*}$ Mabia Khanam Doty, Saima Jahan Liza \\ AND PARVEEN RASHID \\ Plant Physiology, Nutrition and Plant Biochemistry Laboratory, \\ Department of Botany, University of Dhaka, Dhaka-1000, Bangladesh
}

Key words: Momordica charantia, Anatomy, Fibro vascular bundle

\begin{abstract}
Recent investigation on the root, stem, leaf and petiole anatomy of Momordica charantia L. completed the detailed anatomical study of the genus Momordica from Bangladesh. Root has tetrach vascular bundles where thick patches of sclerenchyma cells encompassed the vessel cells. Five angular ridges and furrows are visible through stem transverse section typical to Cucurbitaceae. Total nine open, bicollateral fibro-vascular bundles are observed in stem crosssection where three large are in the center and others each are under the ridges. Midrib of the leaf is characterized by several double and scarcely seated stalkless globular cystoliths in the lower epidermis. Configuration of petiole is octagonal in shape with eight ridges where seven fibro vascular bundles situated as a ring. Stem and leaf has multicellular, unisireate blunt ended conical shaped trichomes where petiole has similar trichomes with both blunt and pointed head.
\end{abstract}

\section{Introduction}

The genus Momordica (Cucurbitaceae) is a native of the Paleotropics(1) and comprises about 59 species $^{(2)}$ distributed in the warm tropics of which about 10 species occur in Southeast Asia(3). Three species of the genus have been reported from Bangladesh and these are Momordica charantia L., M. cochinchinensis (Lour.) Spreng. and M. dioica Roxb. ex Willd ${ }^{(4)}$. Among the three edible vegetables $M$. charantia $L$. is the most popular and cultivated as an economically valued vegetable (local name Korolla, English name bitter gourd, balsam pear). The green and ripe fruits are cooked and consumed as vegetable all over the country because of its availability and high nutritive value. Bitter gourd has a relatively high nutritional value compared to other Cucurbits, due predominantly to the iron, phosphorus, and ascorbic acid content ${ }^{(5,6)}$. The leaves are a good source of calcium, carotene, riboflavin, and ascorbic acid(7). The plant is generally used as a hypoglycemic and antidiabetic agent ${ }^{(8,9)}$. Leaf and fruit extracts are used in the preparation of tea and is a popular health drink in Japan ${ }^{(10,11)}$.

*Author for correspondence: <kishwar.botany@du.ac.bd>. 
Though extensive anatomical investigations have been carried out in $M$. charantia by different researchers throughout the world ${ }^{(12-15)}$ no works have been carried out in our country. Early in the year of 2017 detailed comparative works on the root, stem, leaf and petiole anatomy of $M$. dioica and M. cochinchinensis ${ }^{(16)}$ have been conducted. However, to complete the detailed anatomical studies of genus Momordica from Bangladesh present work has been conducted to investigate the anatomical features of root, stem, leaf and petiole of $M$. charantia by using light microscopy.

\section{Materials and Methods}

Momordica charantia was used as experimental material and dried according to herbarium techniques and stored in Dhaka University Salar Khan Herbarium (DUSH). Information regarding voucher specimen of the material is as follows: Momordica charantia L., collection area - Dhaka University area, collection date-03.09.2017, collected by - KJ Shethi, voucher specimen no. DUSH10796.

Fresh specimens were collected from different regions of Dhaka city including the Botanical garden, Department of Botany, University of Dhaka, for the study of the internal structures of the plant. Free hand sectioning of root, stem, leaf and petiole was done with the help of a razor blade. The sections were stained with safranin and mounted in $20 \%$ glycerin. After that selected sections were prepared as permanent slides. The permanent slides with sections were studied under a compound light microscope (Carl Zeiss Lab A1 microscope) fitted with digital camera (Axiocam ERc 5s). Micrographs were taken from various regions of the sections using different magnifications through Axio Vision Release 4.8.2 software.

\section{Results and Discussion}

Transverse section of root is shown in Fig. 1A from which the contour of root is revealed as roundish. Since the species is perennial periderm is observed replacing the epidermis during secondary growth. Periderm is featured by outward thick walled phellem, followed by one layered meristematic phellogen and inward several layered phelloderm. Chlorophyll containing cells are present in phelloderm (Fig. 1B). Numerous patches of schlerenchyma tissue found scattered in the cortex region. From Fig. 1A it is observed that vascular bundle is tetrarch congruent to the vascular bundles of $M$. dioica and $M$. chochinchinensis and thick patches of sclerenchyma cells surround the vessel cells as $M$. chochinchinensis ${ }^{(16)}$.

Presence of ridges and furrows in stem is a characteristic feature of Cucurbitaceae. The transverse section of stem has typical five ridges and furrows ${ }^{(12)}$ (Fig. 1C). M. dioica has similar pattern though more pointed angles were observed ${ }^{(16)}$. The epidermis is consisted of one layer of compactly arranged rectangular parenchyma cells with thin and 
smooth cuticle. A few blunt ended uniseriate, multicellular conical trichomes are present $^{(12)}$ (Fig. 1D). Collenchyma cells (hypodermis) lie just beneath the epidermis and consists of 6 - 7 layers of cells in the ridges, whereas in the furrows it is 1 - 2 layered. Chlorophyllous cells are also present in hypodermis layer. The stem is characterized by pericycle of continuous ring of a several (4-6) layered irregular shaped sclerenchyma cells (Fig. 1D).
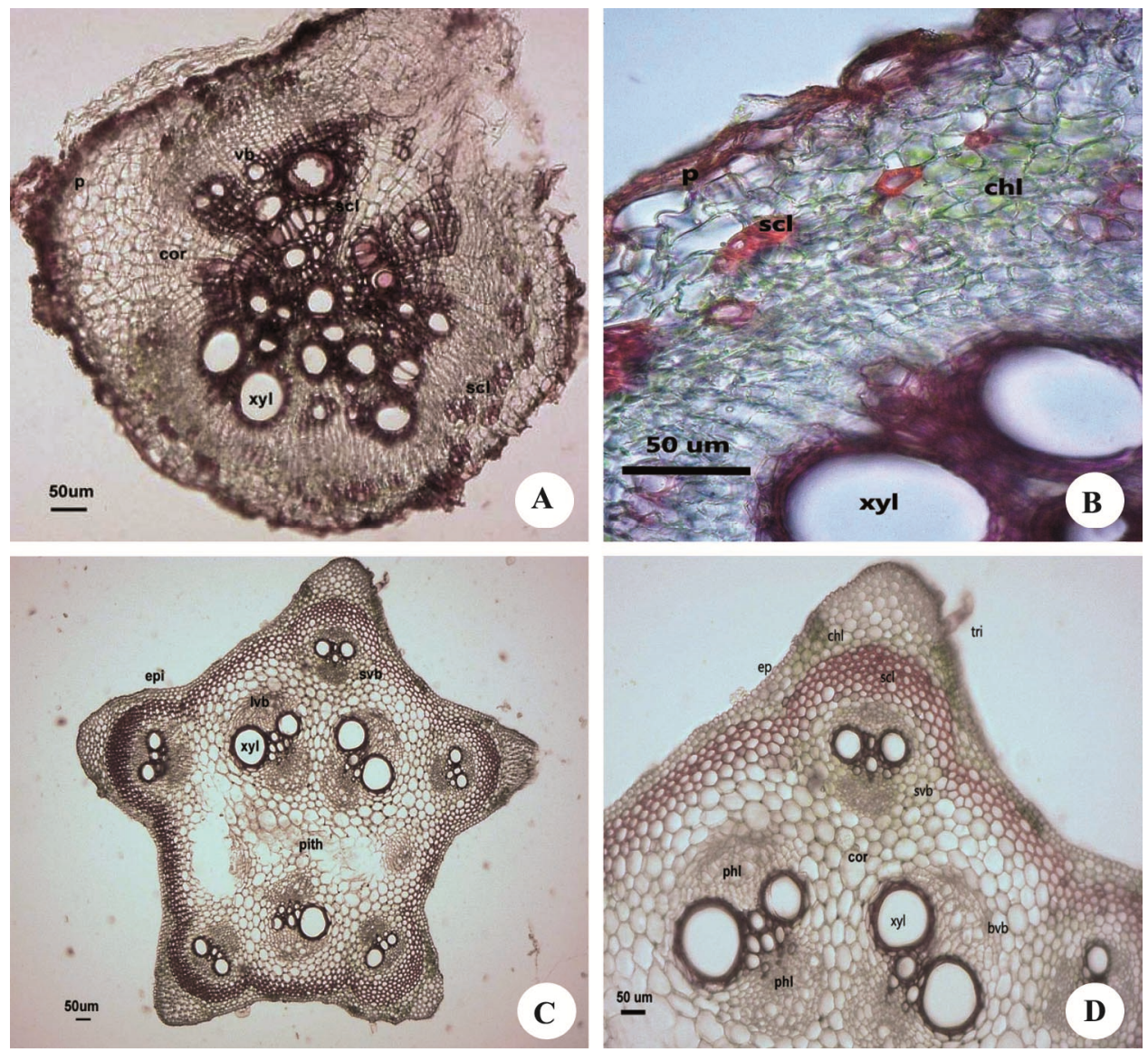

Fig. 1. Transverse section of root of $M$. charantia L. under 50X magnification (A). Patches of sclerenchyma and chlorenchyma cells in the cortex region of the root under 400X magnification (B). Stem transverse section of $M$. charantia L. under 50X magnification (C). Epidermis is followed by collenchyma, chlorenchyma and sclerenhyma cells. Single small fibro-vascular bundle is at one of the ridges whereas large fibro vascular bundles are in center of stem (D) 100X magnification. $\mathrm{p}=$ periderm, $\mathrm{chl}=$ chlorenchyma, $\mathrm{scl}=$ sclerenchyma, $\mathrm{ep}=$ epidermis $, \mathrm{xyl}=\mathrm{xylem}, \mathrm{phl}=\mathrm{phloem}$, $\mathrm{svb}=$ small vascular bundle, $\mathrm{bvb}=$ big vascular bundle, $\mathrm{cor}=$ cortex, tri $=$ trichome. Bar $=50 \mu \mathrm{m}$.

Three bicolatteral, open, well developed fibro-vascular bundles arranged in a ring in the center of the stem. In addition, angles have one fibro-vascular bundle where xylem is 
surrounded by inner and outer phloem (Fig. 1C). However, several researches found 10 vascular bundles arranged in two rings $(13,15)$. Metaxylems of the central vascular bundles are larger than the fibro-vascular bundles situated at the angles. Pith is parenchymatic.

From leaf transverse section of it is observed that midrib is distinct which is bulged towards the abaxial side and projected as angle towards the adaxial side (Fig. 2A) Upper epidermis and lower epidermis of the species have thin cuticle and uniseriate having

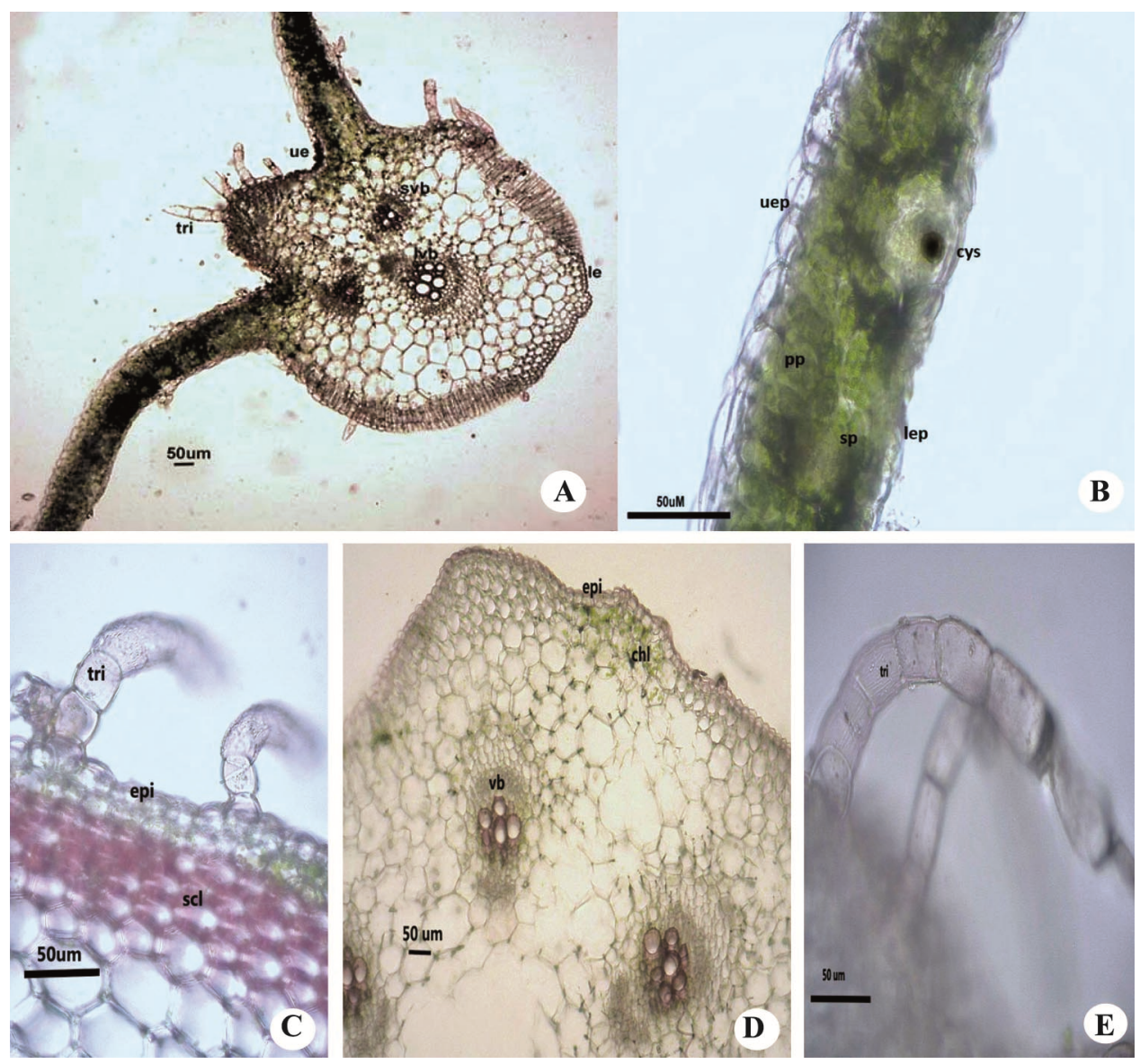

Fig. 2. Midrib showing one well developed vascular bundle and two small vascular bundles toward adaxial side from leaf transverse section of $M$. charantia under 50X magnification (A). Presence of stalkless globular cystoliths on the lower surface of lamina 100X magnification (B) and multicellular trichomes in the midrib under 400X magnification (C). Petiole transverse section of M. charantia (D) 100X magnification. Multicellular hook shaped trichromes on the epidermis of petiole (E) under 400X magnification. ue $=$ upper epidermis, le $=$ lower epidermis, $\mathrm{svb}=$ small vascular bundle, $\mathrm{lvb}=$ large vascular bundle $\mathrm{pp}=$ palisade parenchyma, $\mathrm{sp}=$ spongy parenchyma, cys = cystolith, tri $=$ trichome, epi $=$ epidermis, $\mathrm{chl}=$ chlorenchyma, cor $=$ cortex. Bar $=50 \mu \mathrm{m}$. 
barrel shaped cells. Upper epidermal cells are more flattened compared to lower ones (Fig 2B). Epidermis is followed by several layers of well developed collenchyma cells on both sides of the midrib. The three fibro vascular bundles of the midrib near the proximal portion are arranged as the larger one at the center, the smaller two on each side and above the larger one. Xylem cells are arranged in rows and number of rows ranges from 3-4. Trichomes similar as the stem are found more on the upper surface than the lower and specifically on the adaxial ridge of the midrib (Fig. 2D). Stomata's are mostly present in lower epidermis ${ }^{(12)}$. Palisade tissue has single layer of elongated cylindrical cells beneath the upper epidermis and spongy tissue is compactly arranged with irregular cells. The cells of spongy parenchyma also contain chloroplast but compared to palisade parenchyma less chloroplast are observed. Lower epidermal cells have several double and scarcely seated stalkless globular cystoliths ${ }^{(12,15)}$ (Fig. 2B) which has also been reported in $M$. chochinchinensis ${ }^{(16)}$. It has already been reported that $M$. charantia is a good source of calcium and abundant calcium carbonate crystals in the form of cystoliths and pure crystals as calcium oxalate are found in every part of the plant ${ }^{(17)}$.

The contour of petiole as seen from transverse section is octagonal in shape with eight ridges (Fig. 2C). Epidermis has single layered barrel shaped cells with cuticle. Three to four layers of collenchyma cells found immediately beneath the epidermis with clorenchyma cells mostly in the upper two ridges. Seven fibro- vascular bundles arranged in a ring where the innerrmost is the largest while they gradually decrease in size towards outside (Fig 2C). Ground tissue is parenchymatous with starch depositions (raphides) at the corners. Multicellular, uniseriate both pointed and blunt ended conical and hook shaped trichomes are present similar to M. dioica and M. chochinchinensis (Fig. $2 \mathrm{E})^{(12,16)}$.

In the current study detailed anatomical investigation of $M$. charantia L. was conducted using root, stem, leaf and petiole. This investigation is reported for the first time in Bangladesh as continuation to accomplish anatomical study of Momordica genus from Bangladesh.

\section{References}

1. Robinson RW and DS Decker-Walters 1997. Cucurbits. CABI Publishers, Wallingford, pp. 97-101.

2. Schaefer H and SS Renner 2010. A three-genome phylogeny of Momordica (Cucurbitaceae) suggests seven returns from dioecy to monoecy and recent long distance dispersal to Asia. Mol Phylogenet. Evol. 54: 553-560.

3. de Wildw WJJO and BEE Duyfjes 2002. Synopsis of Momordica (Cucurbitaceae) in SE-Asia and Malesia. Bot. Zhurn. 87: 132-148.

4. Ahmed ZU, MA Hassan, ZNT Begum, M Khondoker, SMH Kabir, ATA Ahmed, AKA Rahman and EU Haque 2008. Encyclopedia of Flora and Fauna of Bangladesh. Angiosperm: Dicotyledons (Balsaminaceae-Euphorbiaceae). Asiatic Society of Bangladesh, Dhaka 7: 312-313. 
5. Oliver AEP 1960. Medicinal plants in Nigeria. College of Arts and Science Technology, River State, Nigeria, pp. 72-73.

6. Morton JF 1967. The balsam pear-an edible, medicinal and toxic plant. Econ. Bot. 21: 57-68.

7. Anonymous 2004. Wide hybridization. In: Rai M, Singh J (Eds) IIVR annual report, 2004. Indian Institute of Vegetable Research, Varanasi, pp. 24.

8. Chen Q, L Laureen, L Chan, T Li Edmund 2003. Bitter melon Momordica charantia reduces adiposity, lowers serum insulin and normalizes glucose tolerance in rats fed a high diet. J. Nutr. 133: 1088-1093.

9. Vikrant V, JK Grover, N Tandon, SS Rathi and N Gupta 2001. Treatment with extracts of Momordica charantia and Eugenia jambolana prevents hyperglycemia and hyperinsulinemia in fructose fed rats. J. Ethnopharmacol. 76:139-143.

10. Tindall HD 1983.Vegetables in the tropics. Macmillan, London. pp. 28.

11. Reyes ME, CBH Gildemacher and GJ Jansen 1994. Momordica L. In: Siemonsma JS and K Piluek (Eds) Plant resources of South-East Asia: vegetables. Pudoc Scientific Publishers, Wageningen, The Netherlands, pp. 206-210.

12. Yasuda A 1903. On the comparative anatomy of the Cucurbitaceae, wild and cultivated, in Japan. J. Sci. Coll. 18(4): 1-56.

13. Aguoru CU and BE Okoli 2012. Comparative stem and petiole anatomy of West African species of Momordica L. (Cucurbitaceae). African J. PI. Sci. 6(15): 403-409.

14. Giuliani C, C Tani and L Maleci Bini 2016. Micromorphology and anatomy of fruits and seeds of bitter melon (Momordica charantia L., Cucurbitaceae). Act Soc. Bot. Pol. 85(1): 3490-3497.

15. Poyraz E and Derdovski 2016. Morpho-anatomical investigations on Momordica charantia L. (Cucurbitaceae). Anadolu Univ. J. Sci and Technology-C-Life. Sci. and Biotech. 5(1): 23-30.

16. Shethi KJ, M Begum and P Rashid 2017. Comparative anatomy of Momordica dioica and M. cochinchinensis (Lour.) Spreng. Bangladesh J. Bot. 46(2): 725-732.

17. Chakravarty HL 1937. Physiological anatomy of the leaves of Cucurbitaceae. Philipp. J. Sci. 63 : 409-431.

(Manuscript received on 17 October, 2017; revised on 26 December, 2017) 